Research papers

\title{
Effects of hydrological events on morphological evolution of a fluvial system
}

\author{
Somayeh Mirzaee ${ }^{\mathrm{a}}$, Saleh Yousefi ${ }^{\mathrm{b}}$, Saskia Keesstra $^{\mathrm{c}}$, Hamid Reza Pourghasemi ${ }^{\mathrm{d}, *}$, Artemi Cerdà , \\ Ian C. Fuller ${ }^{\mathrm{f}}$
}

a Department of Watershed Management, Faculty of Natural Resources, Lorestan University, Khoramabad, Iran

${ }^{\mathbf{b}}$ Faculty of Natural Resources and Marine Sciences, Tarbiat Modares University, Emam Reza Street, Noor 46417-76489, Iran

c Soil Physics and Land Management Group, Wageningen University, Droevendaalsesteeg 4, 6708PB Wageningen, The Netherlands

d Department of Natural Resources and Environmental Engineering, College of Agriculture, Shiraz University, Shiraz, Iran

e Soil Erosion and Degradation Research Group, Departament de Geografia, Universitat de València, Blasco Ibànez 28, 46010 Valencia, Spain

${ }^{\mathrm{f}}$ Innovative River Solutions, School of Agriculture and Environment, Massey University, Palmerston North, New Zealand

\section{A R T I C L E I N F O}

\section{Keywords:}

Flood frequency

Flood magnitude

Channel plan-form

Meander bend

Channel width

Cutoff

Sinuosity

\begin{abstract}
A B S T R A C T
This study quantifies morphological evolution of the Dez River, Iran, from 1955 to 2016. The approach uses a sequence of Landsat images, aerial photos, and topographic maps. In addition, the hydrological data including average daily discharge and yearly maximum discharge at the Dezful hydrological station for the period (1955-2016) were used. The study reach was divided into 48 meander loops from upstream to downstream. Active channel width $(w)$ was determined at $10 \mathrm{~m}$ intervals and changes assessed along the study reach of the Dez River. Morphological indices including sinuosity index; straight meander length; centerline flow length; erosion area; erodible length channel migration; centerline elongation; and radius of curvature were calculated in the reach. Results showed that the study reach of the Dez River changed dramatically in response to major floods, although the general trend is towards a narrowing of active channel width by $38 \%$ in the period 1955-2016. Results show that most of the meander loops in the study area extended and expanded. Between 1989 and 1995, all types of meander change were observed. There was a direct correlation between the frequency of hydrological events (flood days) bigger than 2-years return period and elongation of bends.
\end{abstract}

\section{Introduction}

Rivers represent an important and dynamic landscape feature in the world's great plains and valleys. Fluvial systems in these regions are, however, under threat, coming under increasing pressure from growing populations and the demand placed on water, particularly in drier zones. River systems are used as a source of energy, food, transport and subjected to geopolitics (Surian and Rinaldi, 2003; Yousefi et al., 2017a). Fluvial ecosystems are among the most threatened ecosystems in the world, where pollution, urbanization, bio-invasion or changes in water regime results in degraded landscapes (Das et al., 2014; Luppi et al., 2009a; Thakur et al., 2012).

Change in river morphology results in adjustment of other morphological and ecological characteristics until the river adapts to the new conditions (Camporeale and Ridolfi, 2010; Chu et al., 2006; Csiki and Rhoads, 2014; Engel and Rhoads, 2012; Keesstra et al., 2005; Rhoads et al., 2016; Yousefi et al., 2017a). Morphological evolution of large floodplain rivers has been attributed to direct human intervention (e.g. water abstraction, regulation, dams, bridges, sand mining, and river protection activities) as well as indirect impacts (e.g. land use change, climate change, and population growth) (Camporeale and Ridolfi, 2010; Demir and Hasdemir, 2005; Keesstra et al., 2005; Lofthouse and Robert, 2008; Perucca et al., 2006; Spitz et al., 2001; Yousefi et al., 2017b, 2015b; Zhang et al., 2008). Natural processes are also important (e.g. Gilvear et al., 2000; Hudson and Kesel, 2000). River reach morphologies are an assemblage of hydro-geomorphological forms, and large hydrological events are the most important driving forces of change in these fluvial systems and their parameters (Camporeale and Ridolfi, 2010; Dépret et al., 2015). These changes in river parameters over time need to be considered for urban planning, dam and road construction, erosion and sedimentation (Csiki and Rhoads, 2014; Gordon and Meentemeyer, 2006; Gregory, 2006; Kiss and Blanka, 2012; Kondolf et al., 2007; Ma et al., 2012; Nelson et al., 2013; Vadnais et al., 2012; Yanan et al., 2011).

Many studies have contributed to the relationship between hydrology and fluvial geomorphology (e.g. Peixoto et al., 2009; Camporeale and Ridolfi, 2010; Dépret et al., 2015, 2017; Hooke, 2016), often focusing on the impact of discrete large flood events (e.g. Phillips

\footnotetext{
* Corresponding author.

E-mail address: hr.pourghasemi@shirazu.ac.ir (H.R. Pourghasemi).
} 
2002; Fuller, 2008; Hauer and Habersack, 2009; Milan, 2012; Thompson and Croke, 2013). Fewer studies to date have specifically investigated the frequency of floods on channel morphology (Dépret et al., 2015). Phillips (2002) indicated that flash floods in a forested headwater basin, with recurrence interval (RI) flows $>200$ years, were the only floods to cause significant channel change in $\sim 20$ years. In contrast, Dean and Schmidt (2013) found that a flood in the Rio Grande with RI 13-15-years had significant effects on channel widening, up to 52\%. Dépret et al. (2015) considered the hydrological control on the morphogenesis of low-energy meanders in Cher River, France. They examined the duration, frequency, and intensity of floods on the changes in the river morphology and demonstrated that the river morphology was controlled by low-magnitude hydrological events. However, in a study Hooke (2016b) investigating the morphological impacts of flow events of varying magnitude on ephemeral channels in a semiarid region the opposite was found, as low flows could move sediment load without significantly changing fluvial morphology. Therefore, it is important to assess the effects of hydrology on river evolution; especially the effects of extreme hydrological events on river morphology in a semi-arid climatic setting.

This research has two main aims; i) to quantity of morphological evolution of the Dez River during a 60 year period 1955-2016, and; ii) to assess the role of hydrological event frequency on morphological evolution in a study reach of the Dez River. An understanding of the relationship between flood events and fluvial morphological indexes could be very useful for better management of fluvial systems by watershed managers, urban planners and ecosystem services.

\section{Material and methods}

\subsection{Study area}

The Dez River (Fig. 1) has an average daily discharge of $230 \mathrm{~m}^{3} \mathrm{~s}^{-1}$ and is a tributary of the Karoon River, which is one of the major rivers in south-west Iran. The area of the Dez Basin is about $17,320 \mathrm{~km}^{2}$ and the whole length of the river is approximately $400 \mathrm{~km}$ (Woodbridge et al., 2016). The uplands and headwaters of the Dez River comprise the Zagros Mountains which have a maximum elevation of 4,548 m.a.s.l; in Band-e-Qir confluence the Dez River joins the Karoon River, which in turn discharges into the Arvanrood River in Khoramshahr City (elevation 12 m.a.s.l) (Salarijazi, 2012; Yousefi et al., 2016). The Dez Basin has a large range of elevations and climatic belts, but it is mainly located in a semiarid climate zone (Nourani and Mano, 2007; Salarijazi, 2012; Yousefi et al., 2016). The study area selected is a $153 \mathrm{~km}$ long alluvial deposition reach of the Dez River, located in southern Iran (Fig. 1). The study reach is characterized by a meandering planform with a slope of $0.0261 \%$. The upstream limit of the study reach is located near Shush City, downstream of the Dez Dam that was constructed in 1956. According to the floodplain of the study reach a $1 \mathrm{~km}$ buffer area was defined along the study reach to monitor more spatial changes by using the topographic maps and Arc GIS 4.2 software.

\subsection{Data used}

Landsat images, aerial photos, and topographic maps were used to analyze changes in the river morphology in response to hydrological events (Table 1). The hydrological data including average daily discharge and yearly maximum discharge at the Dezful hydrological station for long period (1955-2016) were analyzed. The Dezful station is the nearest hydrological station to the study reach, located about $10 \mathrm{~km}$ upstream of the study reach itself (Fig. 1), no significant tributaries join the Dez River between the gauging station and the study reach, nor along the $153 \mathrm{~km}$ long study reach. Change in flow along the study reach is therefore not thought to be significant. However, this is an uncertainty for the present study.

Geometric corrections were applied on the aerial photos of 1955 according to 27 ground control points in stable parts of vector roads and residential places in Dezful and Shush cities, also in Band-e-Qir. A geometric correction of these photos was done with a non-parametric polynomial method by ArcGIS 10.2. The total error of corrections was estimated according to root mean standard error (RMSE), and gives $1.78 \mathrm{~m}$ in pixel (Giriraj et al., 2008; Yousefi et al., 2015b). Using true composite images in Landsat data (Red, Green, and Blue bands) and normalized difference water index (NDWI), the active channel for study periods by ENVI 4.8 was extracted (Haibo et al., 2011; Ko et al., 2015; Yousefi et al., 2015a).

Based on 2016 Landsat OLI image, the study reach was divided into 48 meander loops. Using Fluvial Corridor 10.1, the active channel width $(\mathrm{w})$ was determined in $10 \mathrm{~m}$ intervals and changes were detected along the entire $153 \mathrm{~km}$ reach of the Dez River (Roux et al., 2015; Yousefi et al., 2016). In addition, the sinuosity index (Eq. (1)), straight meander length (L), centerline flow length (S), erosion area (EA), erodible length (EL), channel migration (M); (Eq. (2), centerline elongation (E), and radius of curvature (Rc), were calculated to provide morphological indices (Grenfell et al., 2014; Hooke, 2013; Yousefi et al., 2015b).

$\mathrm{S}=\mathrm{C} / \mathrm{L}$

where $\mathrm{S}$ is sinuosity, $\mathrm{C}$ is channel length and $\mathrm{L}$ is straight-line valley length between measurement points

$M=\left(\frac{\sum E A}{\sum E L}\right) / T$

where: $\mathrm{M}$ is migration rate, $\mathrm{T}$ is the duration of period in year, $\mathrm{EA}$ is erosion area and EL is erosion length.

To identify meander evolution there are various classes and models, while most of this methods derived from case studies (Güneralp et al., 2012; Güneralp and Rhoads, 2009; Luppi et al., 2009b; Peixoto et al., 2009; Van De Wiel et al., 2011). In the current study, meander loop changes and their evolution have been defined using's Hooke (1984) model (Fig. 2). This model also has been used by Yousefi et al. (2016) in the Karoon River where the model is applied to detecting morphological changes in an adjacent semi-arid meandering river into which the Dez River flows.

Using the maximum yearly discharge recorded at the Dezful Station the $2,5,20,50$, and 100-years recurrence interval discharges were calculated according to Log-Pearson type III distribution. In addition, using average daily discharge the frequency (number of flood days per year) of the different recurrence interval discharges was calculated for all discrete study periods (cf. Tables 1-3).

A Pearson correlation test was used to statistically analyze the relationship between the frequency of the different recurrence interval discharge in the Dezful Station and change in morphological indices (Bihamta and ZareChahouki, 2010; Dépret et al., 2015; Pfanzagl and Hamböker, 1994; Yousefi et al., 2016). Fig. 3 shows a flowchart of the methodology used in the present study.

\section{Results}

\subsection{Geomorphological evolution}

\subsubsection{Width of active channel}

The average width of the active channel along the $153 \mathrm{~km}$ study reach narrowed significantly between 1955 and 2016 by $\sim 70 \mathrm{~m}$, or $38 \%$ (Fig. 4). The greatest reduction in width occurred in the second study period (1989-1995). The channel width totally decreased about $70 \mathrm{~m}$ (38\%) during 1955-2016. In addition, the single most intensive reduction in active channel width occurred at meander number 22 (cf. Fig. 1), where the average active channel width for this meander reduced from $274 \mathrm{~m}$ in 1955 to $162 \mathrm{~m}$ in 2016. 


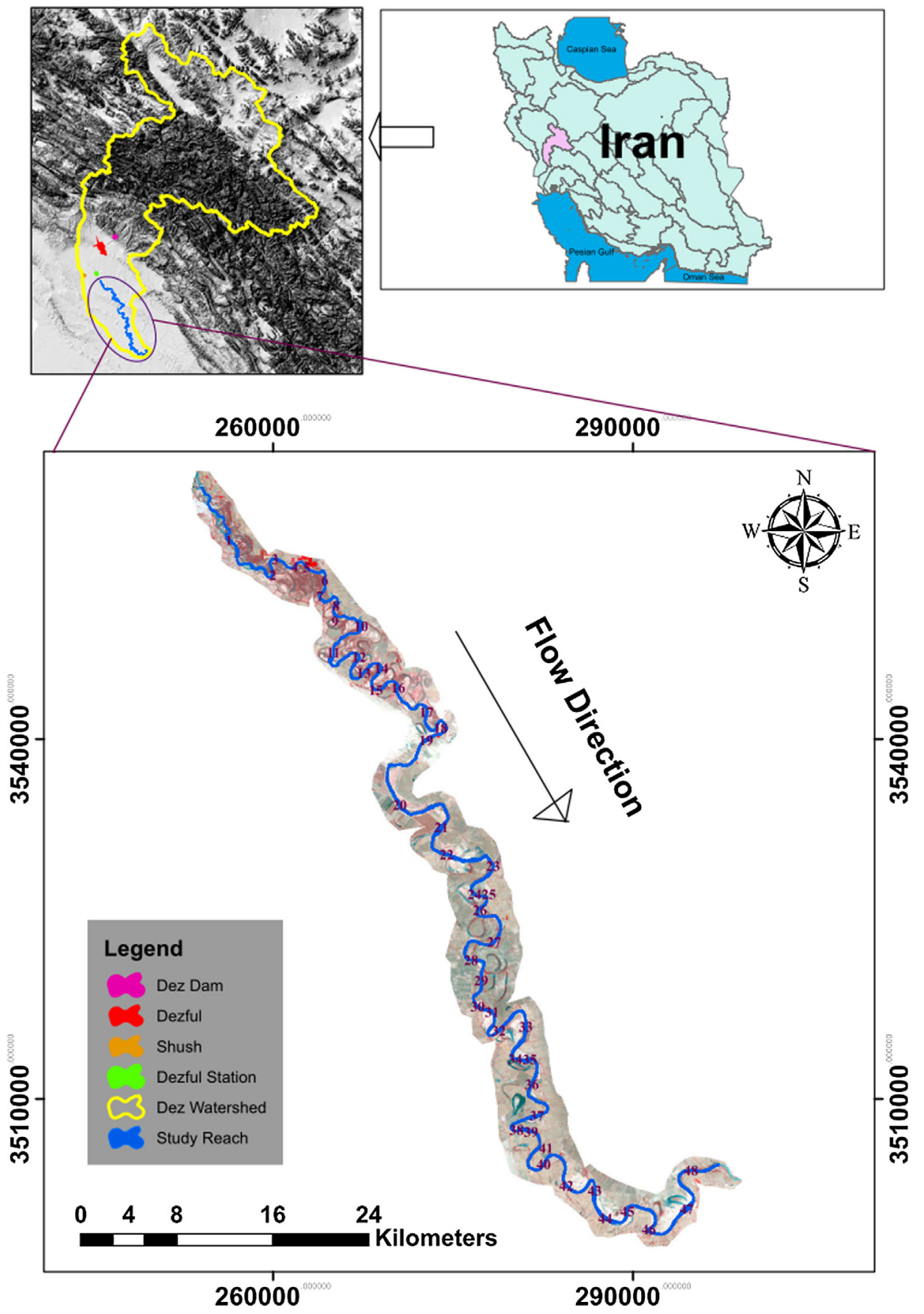

Fig. 1. Location of study area.

\subsubsection{Radius of curvature}

Trends in radius of curvature (Rc) of meanders in the study reach show two directions (Fig. 5). A reduction in Rc initially occurred from 1955 to 1995, before increasing from 1995 to 2016. In general, 1995 is a turning point during the study period. The largest single overall reduction in radius of curvature occurred in meander number 25 , changing from 1.7 in 1955 to 0.38 in 2016.

Table 1

Data used in the study area.

\begin{tabular}{|c|c|c|c|c|}
\hline Data & Date & Scale & Provider & Use \\
\hline Aerial Photo & 12/June/1955 & $1: 30000$ & National Cartographic Center of Iran (NCC) & Channel analysis \\
\hline $\mathrm{TM}$ & 24/May/1989 & $30 * 30 \mathrm{~m}$ & USGS & Channel analysis \\
\hline TM & 30/March/1995 & $30 * 30 \mathrm{~m}$ & USGS & Channel analysis \\
\hline $\mathrm{ETM}+$ & 5/June/2005 & $30 * 30 \mathrm{~m}$ & USGS & Channel analysis \\
\hline OLI & 08/May/2016 & $15 * 15 \mathrm{~m}$ & USGS & Channel analysis \\
\hline Topography Map & 25/March/2001 & $1: 25,000$ & National Cartographic Center of Iran (NCC) & Geometric correction \\
\hline
\end{tabular}




\section{SIMPLE TYPES}

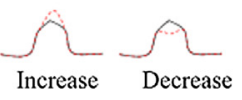

Extension

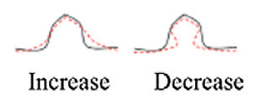

Expansion

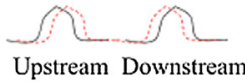

Translation

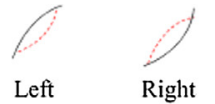

Lateral movement

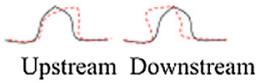

Rotation

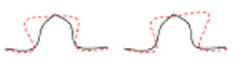

Irregular changes

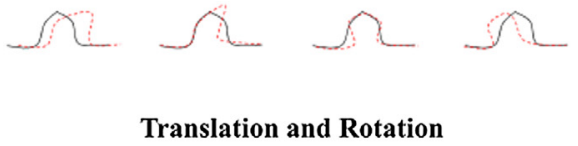

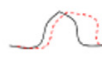

Translation and Expansion

\section{DOUBLE COMBINATIONS}

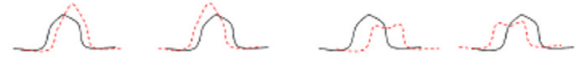

Extension and Translation
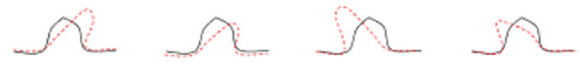
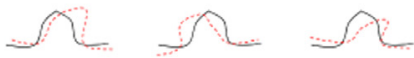

Rotation and Expansion TRIPLE COMBINATIONS

Extension and Rotation

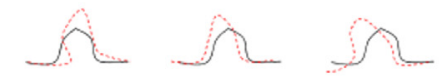

Fig. 2. Model of meander change based on Hooke (1984).

\subsubsection{Sinuosity index}

Results showed that the average sinuosity index during study period decreased from 2.38 to 1.91 (Fig. 6), suggesting an overall straightening of the river course. A dramatic reduction in sinuosity index occurred in the second period (1989-1995). In addition, the rate of reduction in sinuosity index reduced during the last two decades (1995-2016).

\subsubsection{Channel elongation}

Channel elongation in the study reach for four study periods (1955-1989, (1989-1995, 1995-2005 and 2005-2016) was calculated (Fig. 7). Results showed that the most important trend in elongation change occurred in the two periods of 1955-1989 and 1989-1995 with a reduction. However, more recently, for the periods 1995-2005 and 2005-2016 elongation has increased. In addition, the variation of elongation rate in the two first study periods (1955-1989 and 1989-1995) is more intensive than the latter two (1995-2005 and 2005-2016).

\subsubsection{Channel migration}

Channel migration in the study area for all study periods was calculated (Fig. 8). The greatest channel migration was observed for the second period (1989-1995) at $4.2 \mathrm{~m} \mathrm{y}^{-1}$. The general trend of migration rate reduced from $2.66 \mathrm{~m} \mathrm{y}^{-1}(1955-1989)$ to $1.74 \mathrm{~m} \mathrm{y}^{-1}$ (2005-2016).

The meander loop changes and their evolution were classified with reference to Hooke's (1984) change model (cf. Fig. 2) (Table 2). Results show that most of the meander loops extended and expanded (a double combination change). In the second period (1989-1995), all types of
Table 3

Frequency of different recurrence interval discharges in study periods (flood day per year).

\begin{tabular}{llllll}
\hline Period & $\mathrm{Q}>\mathrm{Q} 2$ & $\mathrm{Q}>\mathrm{Q} 5$ & $\mathrm{Q}>\mathrm{Q} 20$ & $\mathrm{Q}>\mathrm{Q} 50$ & $\mathrm{Q}>\mathrm{Q100}$ \\
\hline $1955-1989$ & 4.4 & 1.4 & 0.4 & 0.2 & 0.1 \\
$1989-1995$ & 2.7 & - & - & - & - \\
$1995-2005$ & 9 & 2.9 & 0.6 & 0.2 & 0.1 \\
$2005-2016$ & 4.3 & 0.5 & - & - & - \\
\hline
\end{tabular}

meander change were observed. The rarest type of meander change in the study reaches was Translation and Rotation, this kind of change was observed just for one meander (number 27) in the second period.

\subsection{Hydrology and geomorphology}

Fig. 9 shows the average annual discharge and the annual peak discharge during the study period. The results of Log-Pearson type III distribution show the 2-year (Q2), 5-year (Q5), 10-year (Q10), 20-year (Q20), 50-year (Q50), and 100-year (Q100) recurrence interval discharge in the Dezful gauging station, which are 285, 366, 436, 734, 1,155 and $1,725 \mathrm{~m}^{3} \mathrm{~s}^{-1}$, respectively. Table 3 shows the frequency (number of flood days per year) of different recurrence interval discharges in study periods. Results showed that just in two periods (1955-1989 and 1995-2005), floods with a magnitude of more than Q20 occurred in the study reach. As the number of hydrological events bigger than Q20 did not occur for at least three periods, we considered only the relationship between morphological evolution and Q2 and Q3

Table 2

Frequency of meanders change in different type of evolution.

\begin{tabular}{|c|c|c|c|c|c|c|c|c|c|}
\hline \multirow{2}{*}{$\begin{array}{l}\text { Change } \\
\text { Period }\end{array}$} & \multicolumn{3}{|c|}{ Simple types } & \multicolumn{3}{|c|}{ Double combinations } & \multicolumn{3}{|l|}{ Triple combinations } \\
\hline & Extension & Translation & $\begin{array}{l}\text { Lateral } \\
\text { movement }\end{array}$ & $\begin{array}{l}\text { Extension and } \\
\text { Expansion }\end{array}$ & $\begin{array}{l}\text { Translation and } \\
\text { Rotation }\end{array}$ & $\begin{array}{l}\text { Rotation and } \\
\text { Expansion }\end{array}$ & $\begin{array}{l}\text { Extension, Translation and } \\
\text { Rotation }\end{array}$ & $\begin{array}{l}\text { New } \\
\text { meander }\end{array}$ & Cut off \\
\hline 1955-1989 & 2 & 5 & - & 3 & - & - & - & 1 & 2 \\
\hline 1989-1995 & 4 & 3 & 2 & 24 & 1 & 1 & 1 & 9 & 4 \\
\hline $1995-2005$ & 4 & 1 & 7 & 27 & - & 2 & 2 & 6 & 1 \\
\hline 2005-2016 & 1 & 2 & 3 & 40 & - & - & - & 1 & - \\
\hline
\end{tabular}




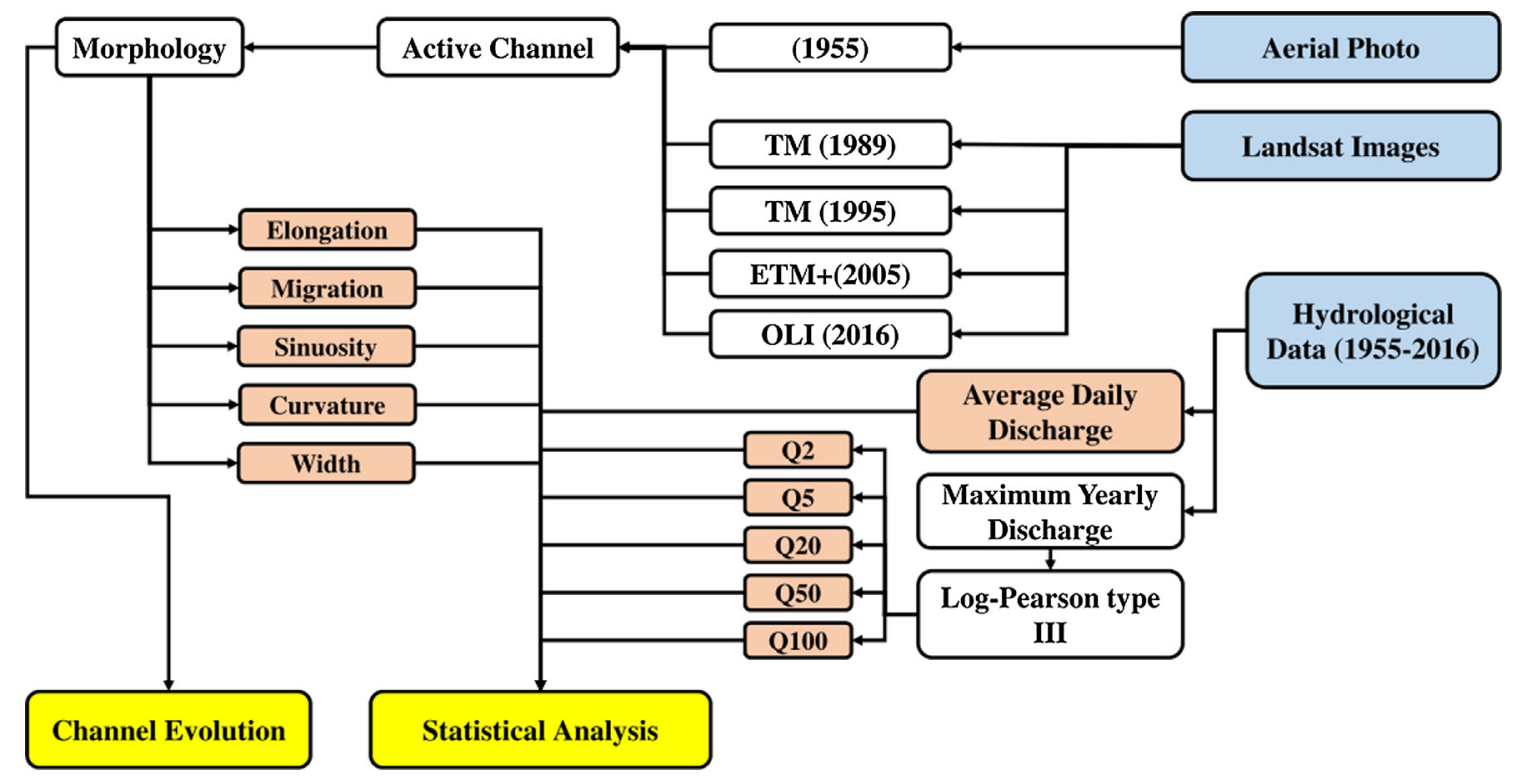

Fig. 3. Flowchart of the used methodology.

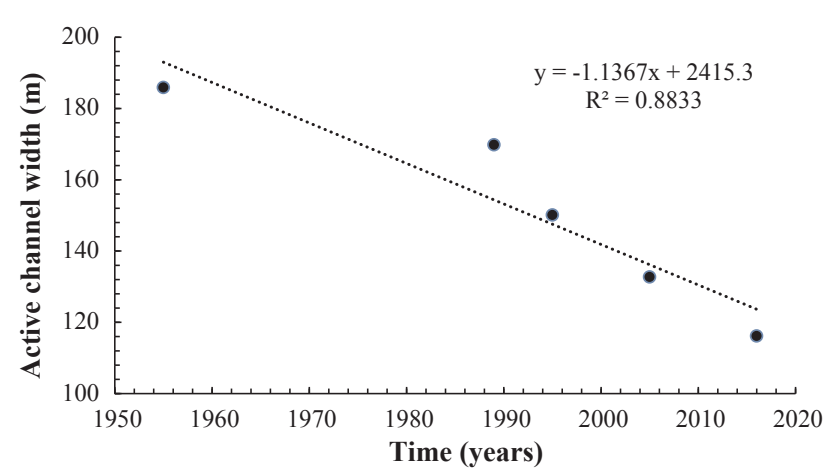

Fig. 4. Active channel width evolution and its trend.

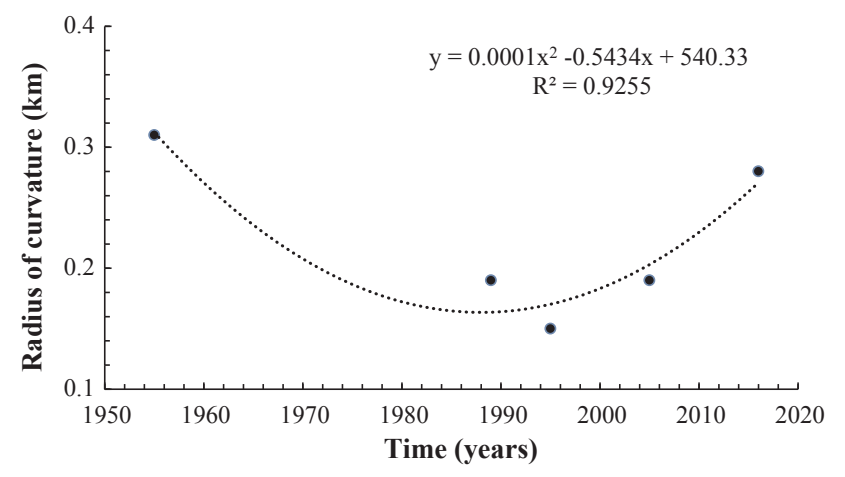

Fig. 5. Evolution of curvature radius during 1950-2016.

events.

The results of a Pearson correlation test show a direct correlation between elongation and sinuosity change versus frequency of events bigger than Q2 at a 5\% significant level. However, for events bigger than Q5 there is a significant correlation at 1\% level with elongation, but the type of correlation is indirect. In addition, there is a direct significant correlation at the $5 \%$ level between frequency of the events bigger than Q5 and migration (Table 4 and Fig. 10). There appears to be no significant correlation between active channel width change and hydrological events of this magnitude.

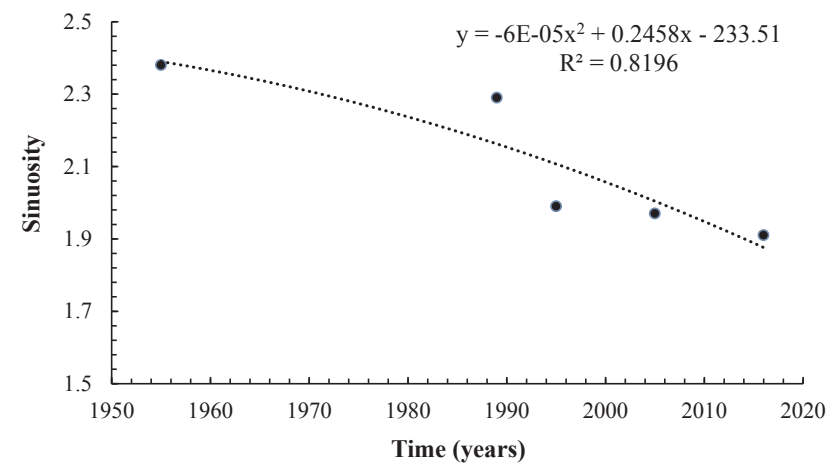

Fig. 6. Evolution of sinuosity index in study reach.

\section{Discussion}

\subsection{Geomorphological evolution}

Direct and indirect driving forces can change the geomorphology of fluvial systems. In the present study, the results showed that the study reach of the Dez River changed significantly. During the entire study period, of 61 years, 17 new meanders and 7 cutoffs were created along the $153 \mathrm{~km}$ study reach. The active channel width reduced. No correlation was found between width and floods exceeding Q2 or Q5, suggesting that width change is in response to human activities in the channel (Hooke, 2016; Latapie et al., 2014; Ollero, 2010; Toone et al., 2014). Both sides of the Dez river have seen an increase in the area used by agriculture and the riparian vegetation has mostly been removed during recent decades. The sinuosity index suggested a reduction in sinuosity (straightening) during the $\sim 60$ year study period, which also appeared to be correlated with smaller flood frequency (see below), but may also reflect direct human intervention in the channel with floodplain development. Radius of curvature changed during the last $\sim 60$ years in the study reach, but with no clear direction. However, lower Rc values recorded in 1989, 1995 and 2005 were coincident with (or immediately followed) the three largest floods in the gauged record (cf. Fig. 9), suggesting bends may have been, on average, smaller, possibly associated with cutoffs in response to these larger floods. The larger radius of curvature values recorded in 1955 and 2016 may reflect discrete bend development. The elongation assessment detected the 


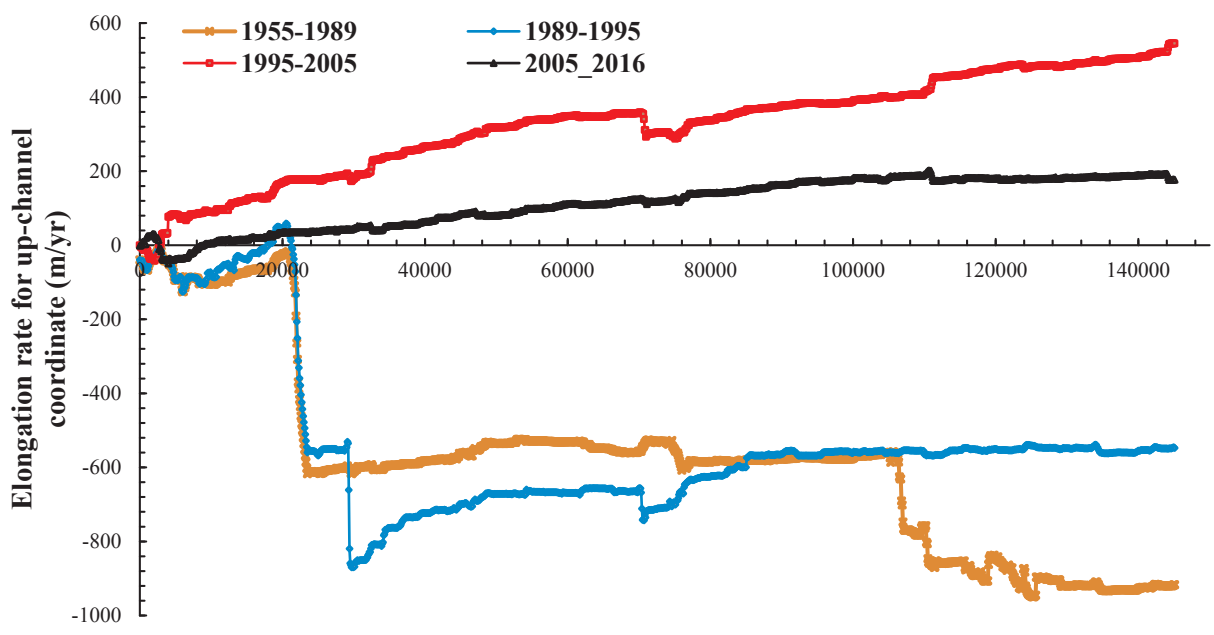

Up-channel coordinate (m)

Fig. 7. Elongation of study reach during four periods.

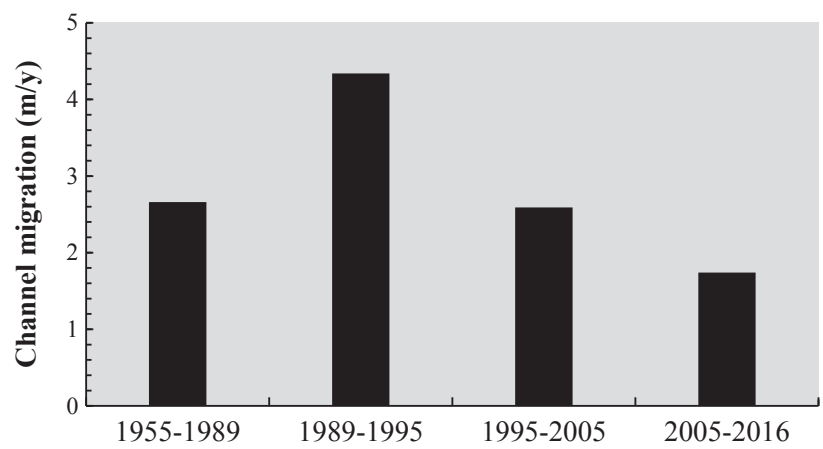

Fig. 8. Channel migration during four periods in study area.

location of cutoffs and meander evolution. Fig. 7 shows that the variation of elongation rate in two first periods is more than the two last periods. In addition, the number of cutoffs in the first two periods exceeds the number in the last two periods. These variations in elongation and cutoffs may reflect hydrological variability in this period (Fig. 9). Once a cutoff occurred, the flow length decreased and the sinuosity and curvature will decrease as a consequences (Frascati and Lanzoni, 2010; Hooke, 2004; Rhoads et al., 2016; Yousefi et al., 2016). The channel migration was highest in the second study period (1989-1995), which
Table 4

Results of Pearson correlation test between frequency of hydrological events and geomorphological evolution.

\begin{tabular}{llllll}
\hline Correlation & Elongation & Migration & Sinuosity & Width \\
\hline \multirow{2}{*}{ Q > Q2 } & Pearson correlation & 0.909 & -0.403 & 0.913 & 0.184 \\
& Significant & $0.046^{*}$ & 0.299 & $0.024^{*}$ & 0.408 \\
\multirow{2}{*}{ Q $>$ Q5 } & Pearson correlation & -0.92 & 0.902 & 0.093 & 0.082 \\
& Significant & $0.001^{* *}$ & $0.045^{*}$ & 0.470 & 0.472
\end{tabular}

* Significant at $5 \%$ confidence level.

** Significant at $1 \%$ confidence level.

is likely to reflect channel response to disturbance by a large flood in 1986 and another in 1995. The number of cutoffs and new meanders for this period are 4 and 9, respectively, and the movement of channel is extremely high. Fig. 11 shows the morphological evolution in some meander loops during the study period.

\subsection{Hydrology and geomorphology}

One of the problems in the present study is the uncertainty between the study reach and hydrological station (about $10 \mathrm{~km}$ ). However, we assumed that the hydrological regimes along the study reach have the

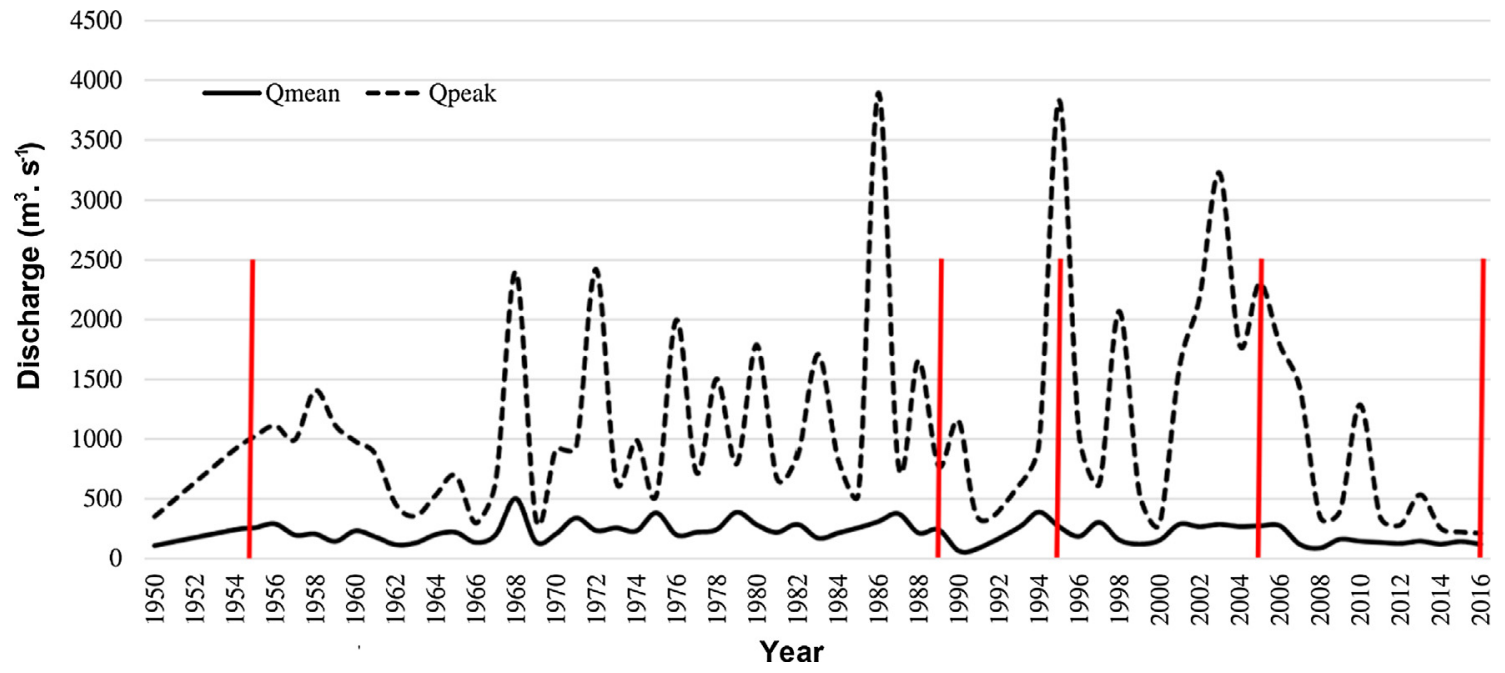

Fig. 9. Annual average and peak discharge during study period. 

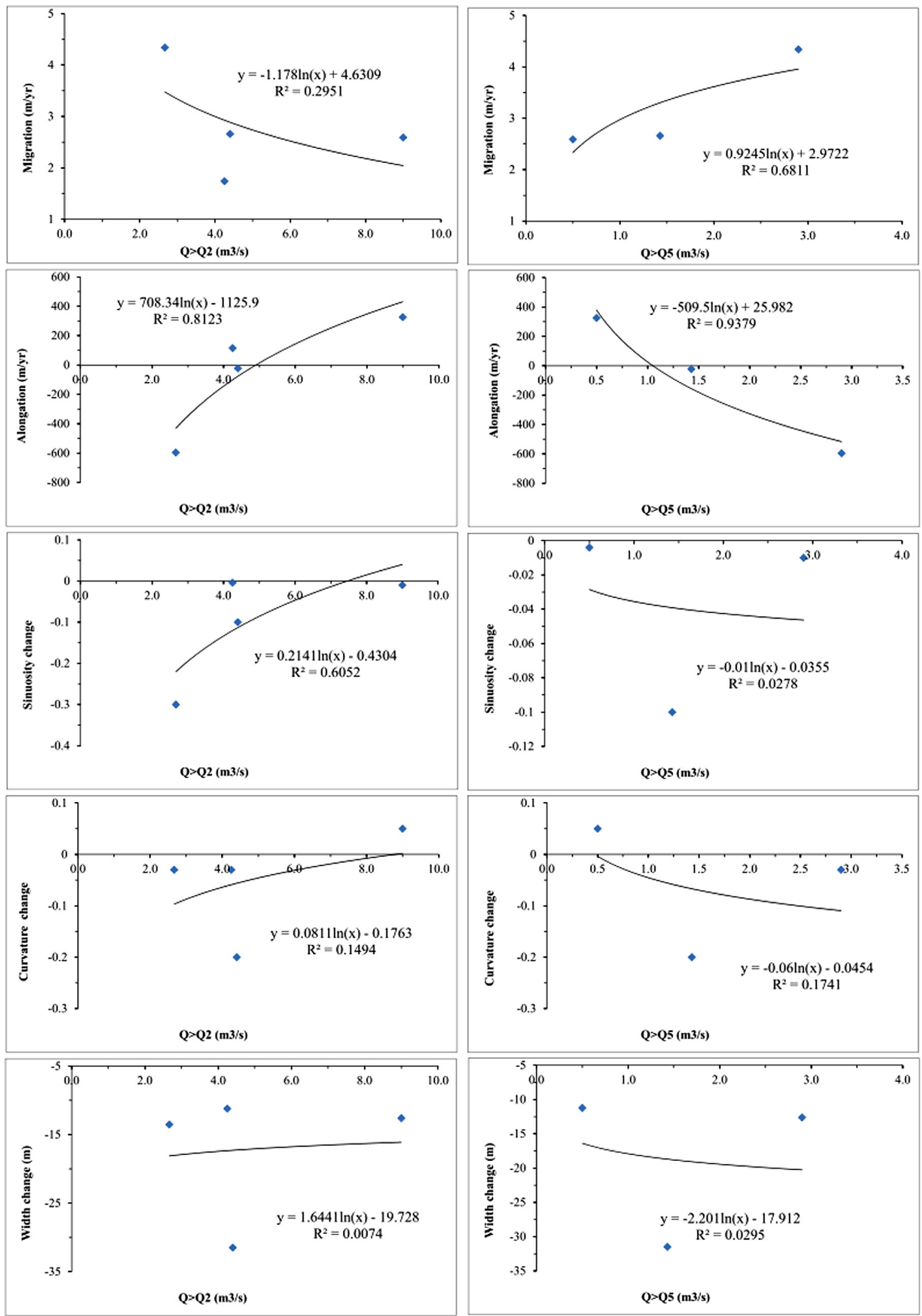

Fig. 10. Correlation between frequency of hydrological events and geomorphological evolution in the study reach.

same behavior, in the absence of significant tributaries. The Dezful gauging station provides the best option for hydrological analysis in this study. The results of Pearson correlation showed that the type of correlation between the frequency of hydrological events (flood days) are bigger than Q2 and the elongation of channel is directly correlated. This suggests that the greater the number of flood days bigger than Q2, 

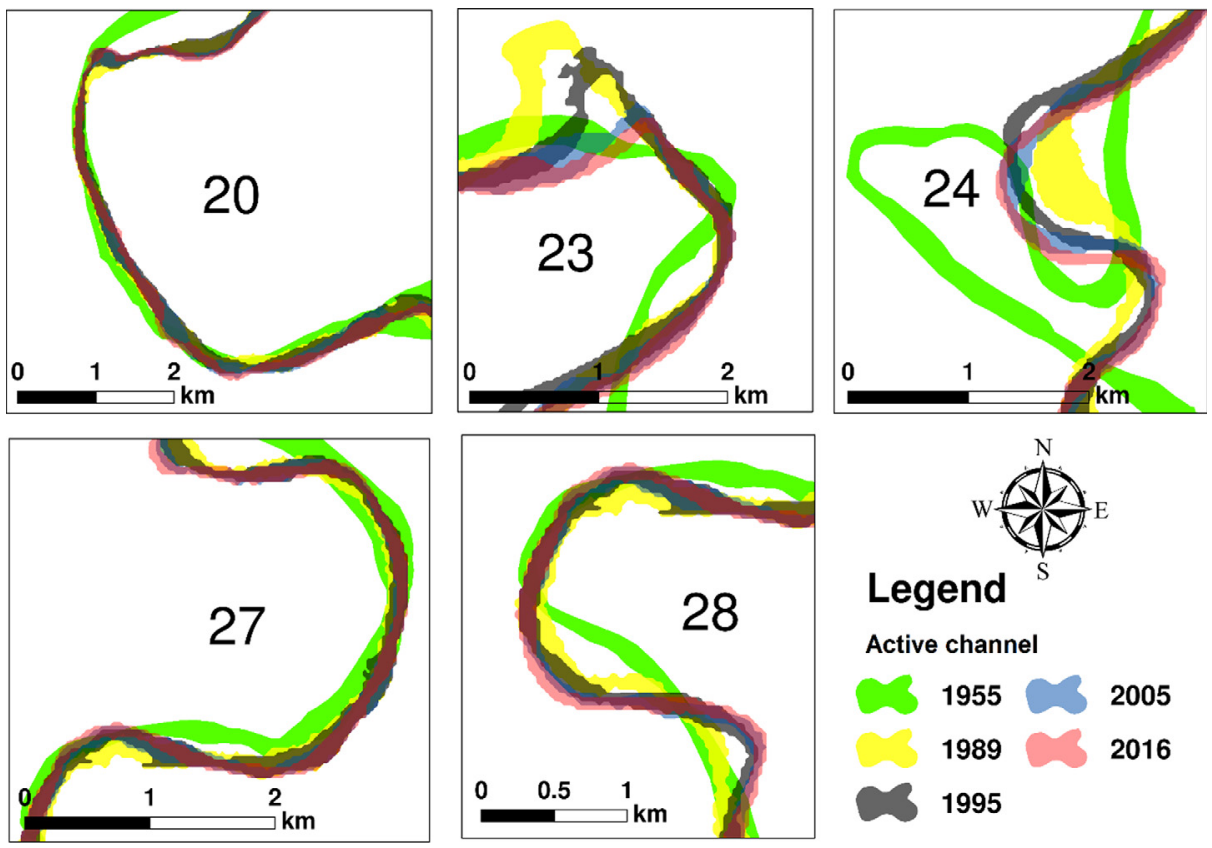

Fig. 11. Morphological evolutions in some meander loops in the Dez River.

the length of the river is expected to increase. However, this relationship for events bigger than Q5 is inverse. Hydrological events less than Q5 play an important role to form the meander loops and the length of the flow will be longer (Camporeale and Ridolfi, 2010; Dépret et al., 2015). By increasing the frequency of floods bigger than Q5, increasing the power of discharge, the bank retreat and the probability of cutoffs occurring in channels will be greater. Channel migration and bank retreat in the study reach have a direct, significant correlation with the frequency of floods greater than Q5. It is generally accepted that bank retreat occurs during hydrological events larger than average (Das et al., 2014; De Rose and Basher, 2011; Posner and Duan, 2012). Dépret et al. (2015) stated that increasing the number of flood days directly increased bank retreat and channel migration. The sinuosity index change and frequency of hydrological events bigger than Q2 have a significant direct correlation, but for frequency of events bigger than Q5 there is no significant correlation with sinuosity change. This can be explained with changes in the flow rate of the river. During periods of higher discharge, bank retreat and channel movement will straighten the course via cutoffs (Hooke, 2004; Rhoads et al., 2016; Toone et al., 2014).

The active channel width of large rivers is mostly controlled by human management actions and very large hydrological events such as flash floods and extreme floods (Alexandrov et al., 2007; Borga et al., 2007; Hooke, 2016). The results here show that the width of the Dez River in the study reach is not significantly correlated with flood frequency (Table 4). Therefore, it is likely that channel reinforcement by river managers plays a definitive role in keeping the width of the river stable during larger floods, and resulting in an overall narrowing.

The lack of data available on water management (including irrigation) in the study reach precludes discussion of the effects of water use in agriculture along the Dez River. Almost all irrigation in the study area uses traditional systems and there is no available data to inform the process of irrigation and water management systems. Further studies should investigate the effects of irrigation and water management on the fluvial evolution of study reach. In this study all the data were generated following the Dez dam construction. The effects of this dam on the Dez River fluvial geomorphology during the study period have not been assessed as a result.

\section{Conclusion}

The evolution of the Dez River in a $153 \mathrm{~km}$ reach during 61 years (1955-2016) was investigated and assessed alongside the hydrological record for the period. The relationship between the frequency of Q > Q2 and Q > Q5 and morphological changes in the study reach were considered in particular. Our findings indicate that the study reach of the Dez River underwent a significant channel narrowing in response to human intervention, rather than any changes in flow magnitude or frequency. The reduction in sinuosity of the study reach was associated with larger floods causing cutoffs, demonstrated by channel elongation. During the study period, 17 new meanders and 9 cutoffs were created along the study reach. Channel migration was maximized during a large-flood dominated period in the late $1980 \mathrm{~s}$ and early $1990 \mathrm{~s}$.

Hydrological events with different return periods play different roles in the morphological evolution in the study reach of the Dez River. Cutoffs and higher migration rates are dependent on extreme and larger discharge events, while progressive bend development takes place during periods dominated by smaller flood events. The findings of this study could help understand the evolution of fluvial systems, particularly where flooding regimes are predicted to change in response to warming climate.

\section{Acknowledgement}

The authors would like to thank anonymous reviewers and Dr. Fernando A.L. Pacheco for their helpful comments on the primary version of the manuscript. Also, we would like to extend our gratitude to Dr. Jesús Mateo-Lázaro (Associate Editor Journal of Hydrology). The Authors would like to especially thank Prof. Herve Piegay and Dr. Thomas Depret for their support and ideas during this research while Saleh Yousefi and Somayeh Mirzaee was hosted at CNRS, ENS-Lyon.

\section{References}

Alexandrov, Y., Laronne, J.B., Reid, I., 2007. Intra-event and inter-seasonal behaviour of suspended sediment in flash floods of the semi-arid northern Negev, Israel. Geomorphology 85, 85-97. http://dx.doi.org/10.1016/j.geomorph.2006.03.013. Bihamta, M.R., ZareChahouki, M., 2010. Principle Statistics in Natural Resources. Tehran University Press, Tehran. 
Borga, M., Boscolo, P., Zanon, F., Sangati, M., 2007. Hydrometeorological analysis of the 29 August 2003 flash flood in the Eastern Italian Alps. J. Hydrometeorol. 8, 1049-1067. http://dx.doi.org/10.1175/JHM593.1.

Camporeale, C., Ridolfi, L., 2010. Interplay among river meandering, discharge stochasticity and riparian vegetation. J. Hydrol. 382, 138-144. http://dx.doi.org/10.1016/j. jhydrol.2009.12.024.

Chu, Z.X., Sun, X.G., Zhai, S.K., Xu, K.H., 2006. Changing pattern of accretion/erosion of the modern Yellow River (Huanghe) subaerial delta, China: Based on remote sensing images. Mar. Geol. 227, 13-30. http://dx.doi.org/10.1016/j.margeo.2005.11.013.

Csiki, S.J.C., Rhoads, B.L., 2014. Influence of four run-of-river dams on channel morphology and sediment characteristics in Illinois, USA. Geomorphology 206, 215-229. http://dx.doi.org/10.1016/j.geomorph.2013.10.009.

Das, T.K., Haldar, S.K., Das Gupta, I., Sen, S., 2014. River bank erosion induced human displacement and its consequences. Living Rev. Landsc. Res. 8. http://dx.doi.org/10. 12942/lrlr-2014-3.

De Rose, R.C., Basher, L.R., 2011. Measurement of river bank and cliff erosion from sequential LIDAR and historical aerial photography. Geomorphology 126, 132-147. http://dx.doi.org/10.1016/j.geomorph.2010.10.037.

Dean, D.J., Schmidt, J.C., 2013. The geomorphic effectiveness of a large flood on the Rio Grande in the Big Bend region: Insights on geomorphic controls and post-flood geomorphic response. Geomorphology 201, 183-198. http://dx.doi.org/10.1016/j. geomorph.2013.06.020.

Demir, M., Hasdemir, M., 2005. Functional planning criterion of forest road network systems according to recent forestry development and suggestion in Turkey. Am. J. Environ. Sci 1, 22-28.

Dépret, T., Gautier, E., Hooke, J., Grancher, D., Virmoux, C., Brunstein, D., 2017. Causes of planform stability of a low-energy meandering gravel-bed river (Cher River, France). Geomorphology 285, 58-81.

Dépret, T., Gautier, E., Hooke, J., Grancher, D., Virmoux, C., Brunstein, D., 2015. Hydrological controls on the morphogenesis of low-energy meanders (Cher River, France). J. Hydrol. 531, 877-891. http://dx.doi.org/10.1016/j.jhydrol.2015.10.035.

Engel, F.L., Rhoads, B.L., 2012. Interaction among mean flow, turbulence, bed morphology, bank failures and channel planform in an evolving compound meander loop. Geomorphology 163-164, 70-83. http://dx.doi.org/10.1016/j.geomorph.2011.05. 026.

Frascati, A., Lanzoni, S., 2010. Long-term river meandering as a part of chaotic dynamics? A contribution from mathematical modelling. Earth Surf. Process. Landforms 35, 791-802. http://dx.doi.org/10.1002/esp.1974.

Fuller, I.C., 2008. Geomorphic impacts of a 100-year flood: Kiwitea Stream, Manawatu catchment, New Zealand. Geomorphology 98, 84-95. http://dx.doi.org/10.1016/j. geomorph.2007.02.026.

Gilvear, D., Winterbottom, S., Sichingabula, H., 2000. Character of channel planform change and meander development: Luangwa River. Zambia. Earth Surf. Process. Landforms 25, 421-436. http://dx.doi.org/10.1002/(SICI)1096-9837(200004) 25:4<421::AID-ESP65>3.0.CO;2-Q.

Giriraj, A., Irfan-Ullah, M., Murthy, M.S.R., Beierkuhnlein, C., 2008. Modelling spatial and temporal forest cover change patterns (1973-2020): A case study from South Western Ghats (India). Sensors 8, 6132-6153. http://dx.doi.org/10.3390/s8106132.

Gordon, E., Meentemeyer, R.K., 2006. Effects of dam operation and land use on stream channel morphology and riparian vegetation. Geomorphology 82, 412-429. http:// dx.doi.org/10.1016/j.geomorph.2006.06.001.

Gregory, K.J., 2006. The human role in changing river channels. Geomorphology 79 172-191. http://dx.doi.org/10.1016/j.geomorph.2006.06.018.

Grenfell, M.C., Nicholas, A.P., Aalto, R., 2014. Mediative adjustment of river dynamics: The role of chute channels in tropical sand-bed meandering rivers. Sediment. Geol. 301, 93-106. http://dx.doi.org/10.1016/j.sedgeo.2013.06.007.

Güneralp, I., Abad, J.D., Zolezzi, G., Hooke, J., 2012. Advances and challenges in meandering channels research. Geomorphology 163-164, 1-9. http://dx.doi.org/10. 1016/j.geomorph.2012.04.011.

Güneralp, I., Rhoads, B.L., 2009. Empirical analysis of the planform curvature-migration elation of meandering rivers. Water Resour. Res. 45, 1-15. http://dx.doi.org/10. 1029/2008WR007533.

Haibo, Y., Zongmin, W., Hongling, Z., Yu, G., 2011. Water body extraction methods study based on RS and GIS. Procedia Environ. Sci. 10, 2619-2624.

Hauer, C., Habersack, H., 2009. Morphodynamics of a 1000-year flood in the Kamp River, Austria, and impacts on floodplain morphology. Earth Surf. Process. Landforms 34 654-682. http://dx.doi.org/10.1002/esp.1763.

Hooke, J.M., 2016. Morphological impacts of flow events of varying magnitude on ephemeral channels in a semiarid region. Geomorphology 252, 128-143. http://dx. doi.org/10.1016/j.geomorph.2015.07.014.

Hooke, J.M., 2013. River Meandering, Treatise on Geomorphology. Elsevier Ltd. 10.1016/B978-0-12-374739-6.00241-4.

Hooke, J.M., 2004. Cutoffs galore!: Occurrence and causes of multiple cutoffs on a meandering river. Geomorphology 61, 225-238. http://dx.doi.org/10.1016/j. geomorph.2003.12.006

Hudson, P.F., Kesel, R.H., 2000. Channel migration and meander-bend curvature in the lower Mississippi River prior to major human modification. Geology 28, 531-534 doi: 10.1130/0091-7613(2000) $28<531$ :CMAMCI > 2.0.CO;2.

Keesstra, S.D., van Huissteden, J., Vandenberghe, J., Van Dam, O., de Gier, J., Pleizier, I.D., 2005. Evolution of the morphology of the river Dragonja (SW Slovenia) due to land-use changes. Geomorphology 69, 191-207. http://dx.doi.org/10.1016/j. geomorph.2005.01.004

Kiss, T., Blanka, V., 2012. River channel response to climate- and human-induced hydrological changes: case study on the meandering Hernád River, Hungary. Geomorphology 175-176, 115-125. http://dx.doi.org/10.1016/j.geomorph.2012. 07.003 .
Ko, B.C., Kim, H.H., Nam, J.Y., 2015. Classification of potential water bodies using Landsat 8 OLI and a combination of two boosted random forest classifiers. Sensors 15, 13763-13777.

Kondolf, G.M., Piégay, H., Landon, N., 2007. Changes in the riparian zone of the lower Eygues River, France, since 1830. Landsc. Ecol. 22, 367-384. http://dx.doi.org/10. 1007/s10980-006-9033-y.

Latapie, a., Camenen, B., Rodrigues, S., Paquier, a., Bouchard, J.P., Moatar, F., 2014. Assessing channel response of a long river influenced by human disturbance. Catena 121, 1-12. http://dx.doi.org/10.1016/j.catena.2014.04.017.

Lofthouse, C., Robert, A., 2008. Riffle-pool sequences and meander morphology. Geomorphology 99, 214-223. http://dx.doi.org/10.1016/j.geomorph.2007.11.002.

Luppi, L., Rinaldi, M., Teruggi, L.B., Darby, S.E., Nardi, L., 2009a. Monitoring and numerical modelling of riverbank erosion processes: a case study along the Cecina River (central Italy) 2148, pp. 2133-2148. doi:10.1002/esp.

Luppi, L., Rinaldi, M., Teruggi, L.B., Darby, S.E., Nardi, L., 2009b. Monitoring and numerical modelling of riverbank erosion processes: a case study along the Cecina River (central Italy) 248, pp. 230-248. doi:10.1002/esp.

Ma, Y., Huang, H.Q., Nanson, G.C., Li, Y., Yao, W., 2012. Channel adjustments in response to the operation of large dams: the upper reach of the lower Yellow River. Geomorphology 147-148, 35-48. http://dx.doi.org/10.1016/j.geomorph.2011.07. 032 .

Milan, D.J., 2012. Geomorphic impact and system recovery following an extreme flood in an upland stream: Thinhope Burn, northern England, UK. Geomorphology 138, 319-328. http://dx.doi.org/10.1016/j.geomorph.2011.09.017.

Nelson, N.C., Erwin, S.O., Schmidt, J.C., 2013. Spatial and temporal patterns in channel change on the Snake River downstream from Jackson Lake dam, Wyoming. Geomorphology 200, 132-142. http://dx.doi.org/10.1016/j.geomorph.2013.03.019.

Nourani, V., Mano, A., 2007. Semi-distributed flood runoff model at the subcontinental scale for southwestern Iran. Hydrol. Process. 21, 3173-3180. http://dx.doi.org/10. 1002/hyp.6549.

Ollero, A., 2010. Channel changes and floodplain management in the meandering middle Ebro River, Spain. Geomorphology 117, 247-260. http://dx.doi.org/10.1016/j. geomorph.2009.01.015

Peixotoa, J.M., Nelson, B.W., Wittmann, F., 2009. Spatial and temporal dynamics of river channel migration and vegetation in central Amazonian white-water floodplains by remote-sensing techniques. Remote Sens. Environ. 113, 2258-2266. http://dx.doi. org/10.1016/j.rse.2009.06.015.

Perucca, E., Camporeale, C., Ridolfi, L., 2006. Influence of river meandering dynamics on riparian vegetation pattern formation. J. Geophys. Res. Biogeosci. 111, 1-9. http:// dx.doi.org/10.1029/2005JG000073.

Pfanzagl, J., Hamböker, R., 1994. Parametric Statistical Theory. Walter de Gruyter.

Phillips, J.D., 2002. Geomorphic impacts of flash flooding in a forested headwater basin. J. Hydrol. 269, 236-250. http://dx.doi.org/10.1016/S0022-1694(02)00280-9.

Posner, A.J., Duan, J.G., 2012. Simulating river meandering processes using stochastic bank erosion coefficient. Geomorphology 163-164, 26-36. http://dx.doi.org/10. 1016/j.geomorph.2011.05.025.

Rhoads, B.L., Lewis, Q.W., Andresen, W., 2016. Historical changes in channel network extent and channel planform in an intensively managed landscape: natural versus human-induced effects. Geomorphology 252, 17-31. http://dx.doi.org/10.1016/j. geomorph.2015.04.021.

Roux, C., Alber, A., Bertrand, M., Vaudor, L., Piégay, H., 2015. "FluvialCorridor": a new ArcGIS toolbox package for multiscale riverscape exploration. Geomorphology 242, 29-37. http://dx.doi.org/10.1016/j.geomorph.2014.04.018.

Salarijazi, M., 2012. Trend and change-point detection for the annual stream-flow series of the Karun River at the Ahvaz hydrometric station. African J. Agric. Res. 7, 4540-4552. http://dx.doi.org/10.5897/AJAR12.650.

Spitz, W., Lagasse, P., Schumm, S., Zevenbergen, L., 2001. A Methodology for Predicting Channel Migration NCHRP Project No. 24-16, Nchrp. doi: 10.1061/40581(2001)106.

Surian, N., Rinaldi, M., 2003. Morphological response to river engineering and management in alluvial channels in Italy. Geomorphology 50, 307-326.

Thakur, P.K., Laha, C., Aggarwal, S.P., 2012. River bank erosion hazard study of river Ganga, upstream of Farakka barrage using remote sensing and GIS. Nat. Hazards 61, 967-987. http://dx.doi.org/10.1007/s11069-011-9944-z.

Thompson, C., Croke, J., 2013. Geomorphic effects, flood power, and channel competence of a catastrophic flood in confined and unconfined reaches of the upper Lockyer valley, southeast. Geomorphology 197, 156-169. http://dx.doi.org/10.1016/j. geomorph.2013.05.006.

Toone, J., Rice, S.P., Piégay, H., 2014. Spatial discontinuity and temporal evolution of channel morphology along a mixed bedrock-alluvial river, upper DrÔme River, southeast France: contingent responses to external and internal controls. Geomorphology 205, 5-16. http://dx.doi.org/10.1016/j.geomorph.2012.05.033.

Vadnais, M.Ė., Assania, A., Landry, R., Leroux, D., Gratton, D., 2012. Analysis of the effects of human activities on the hydromorphological evolution channel of the SaintMaurice River downstream from La Gabelle dam (Quebec, Canada). Geomorphology 175-176, 199-208. http://dx.doi.org/10.1016/j.geomorph.2012.07.010.

Van De Wiel, M.J., Coulthard, T.J., Macklin, M.G., Lewin, J., 2011. Modelling the response of river systems to environmental change: Progress, problems and prospects for palaeo-environmental reconstructions. Earth-Science Rev. 104, 167-185. http:// dx.doi.org/10.1016/j.earscirev.2010.10.004

Woodbridge, K.P., Parsons, D.R., Heyvaert, V.M.A., Walstra, J., Frostick, L.E., 2016. Characteristics of direct human impacts on the rivers Karun and Dez in lowland south-west Iran and their interactions with earth surface movements. Quat. Int. 392, 315-334. http://dx.doi.org/10.1016/j.quaint.2015.10.088.

Yanan, L., Yuliang, Q., Yue, Z., 2011. Dynamic monitoring and driving force analysis on rivers and lakes in Zhuhai City using remote sensing technologies. Procedia Environ. Sci. 10, 2677-2683. http://dx.doi.org/10.1016/j.proenv.2011.09.416. 
Yousefi, S., Keesstra, S., Pourghasemi, H.R., Surian, N., Mirzaee, S., 2017a. Interplay between river dynamics and international borders: The Hirmand River between Iran and Afghanistan. Sci. Total Environ. 586, 492-501.

Yousefi, S., Khatami, R., Mountrakis, G., Mirzaee, S., Pourghasemi, H.R., Tazeh, M., 2015a. Accuracy assessment of land cover/land use classifiers in dry and humid areas of Iran. Environ. Monit. Assess. 187, 461. http://dx.doi.org/10.1007/s10661-0154847-1.

Yousefi, S., Moradi, H.R., Keesstra, S., Pourghasemi, H.R., Navratil, O., Hooke, J., 2017b. Effects of urbanization on river morphology of the Talar River, Mazandarn Province. Iran. Geocarto Int. 1-17. http://dx.doi.org/10.1080/10106049.2017.1353645.

Yousefi, S., Moradi, H.R., Tevari, A., Vafakhah, M., 2015b. Monitoring of fluvial systems using RS and GIS (Case study: Talar River, Iran). J. Selçuk Univ. Nat. Appl. Sci. 4, $60-72$

Yousefi, S., Pourghasemi, H.R., Hooke, J., Navratil, O., Kidova, A., 2016. Changes in morphometric meander parameters identified on the Karoon River, Iran, using remote sensing data. Geomorphology 271, 55-64. http://dx.doi.org/10.1016/j. geomorph.2016.07.034.

Zhang, B., Ai, N., Huang, Z., Yi, C., Qin, F., 2008. Meanders of the Jialing River in China: Morphology and formation. Chinese Sci. Bull. 53, 267-281. http://dx.doi.org/10. 1007/s11434-007-0516-2.

\section{Further Reading}

Beechie et al. (2006) investigated the channel pattern and river-floodplain dynamics in a forested watershed, finding that spatial mobility of straight channels is lower than meandering channels. 